\title{
Learning Of Creative Products And Entrepreneurship In Improving Work Readiness Of Tata Boga Vocational School Students
}

\author{
Yunus Karyanto $^{\mathrm{a}}$, Marji ${ }^{\mathrm{b}}$, Nunung Nurjanah ${ }^{\mathrm{c}}$, Didik Nurhadid, Hari Karyono ${ }^{\mathrm{e}}$, Wawan Gunawan ${ }^{\mathrm{f}}$

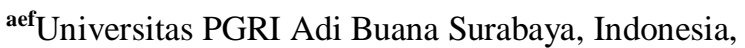

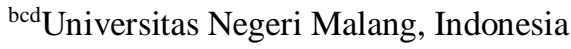 \\ Email: ${ }^{a}$ kar_yns@yahoo.co.id, bmardji.ft@um.ac.id, ${ }^{c}$ nunung.nurjanah.ft@um.ac.id, didik.nurhadi.ft@um.ac.id, \\ eharikaryono@unipasby.ac.id, ${ }_{2}$ wawan.gunawan@unipasby.ac.id
}

\begin{abstract}
:
This study aims to describe the learning of Creative Products and Entrepreneurship in improving job readiness of students of SMK Tata Boga. This research approach is a qualitative approach. This research site at 4 vocational high schools in Surabaya. Data collection techniques used include observation, interviews, documentation and FGD. The results showed that: (1) Learning Creative Products and Entrepreneurship is in accordance with Basic Competencies with learning resources for books, the internet, direct learning in the business world and industry, cultivating active attitudes and critical thinking, and by applying the Production Based Teaching Model learning model; (2) student work readiness is shown by being able to make planning, production, integrated marketing and evaluation, opening their own business through online stores, and being able to open their own job fields, and (3) innovations in food products by students as a provision for work readiness shown by: (a) making processed food products with innovations that are of interest to the public including ingredients, texture, appearance, taste and creativity, processing techniques, decorating, packaging and presentation, and (b) selling products directly and online and marketing brochures, social media and the open pre order system. Based on the results of this study, it can be concluded that learning Creative Products and Entrepreneurship for students of SMK Tata Catering can improve student competence in making business plans, processing, marketing products both directly and online and being able to open their own businesses, so that students have work readiness in the culinary sector .
\end{abstract}

Keywords:

learning creative and entrepreneurial products, job readiness, students of SMK Tata Catering

\section{PRELIMINARY}

The 21 st century is marked by a very rapid global exchange of information. On the other hand, various new skills are needed to withstand all the challenges present in the 21 st century. This situation requires educational institutions such as SMKs to continue to innovate in the educational process to improve the quality of graduates who are ready to work.

SMK is a secondary education that prepares students to be ready to work following the field. Currently, advances in technology and knowledge and globalization have made the goods and services industry continue to develop. Increasing the industrial sector will open up many workforce opportunities, including vocational graduates who have work readiness. Work readiness is the overall condition of a person responding according to the ability of knowledge, skills, and attitudes in the type of work done in the work environment following their potential (Wahyuningsih \& Yulianto, 2020)
SMK graduates are expected to be job seekers in the future and as job opportunities for many people. To be able to open employment opportunities, students are expected to have entrepreneurial readiness. Of course, to start entrepreneurship, some things must be prepared and planned correctly, one of which is the mental, attitude, spirit, and behavior, no longer using the previous paradigm but the mindset of an entrepreneur (Ciana \& Rahmi, 2020).

The new paradigm of secondary vocational learning, namely learning that pays attention to demand-driven, refers to the competency standards that apply in the world of work or the world of industry (Indonesian National Work Competency Standards), implemented with a dual system in schools and industry or the business world, in the form of real activities.

A teacher is expected to determine the appropriate teaching approach in the teaching and learning process in teaching. To improve student reasoning in the teaching and learning process, it is 
also necessary to create a strategy that can increase student attention to the subject matter in the approach process. Students must act and act actively so that the teaching and learning process's objectives can be achieved well (Andriani et al., 2020; Gunawan, Nyoman Sudana Degeng, \& Utaya, 2019).

According to Maulana, Susilo \& Riyadi (2015) the growth of culinary business products in Indonesia will continue to increase every year due to an increase in domestic demand due to the growing development of middle-class consumers. This can lead to more business opportunities for culinary business products in the country. The more excellent the opportunity, the greater the competition in culinary business products. It is necessary to increase Human Resources in producing the best culinary business products to be interested in. According to (Adrianto 2016), products or services viewed from current economic value are no longer determined by raw materials or production systems alone, but rather focus on using creativity and innovation in line with technological developments.

Learning Creative Products and Entrepreneurship is needed to develop students' professional and independent attitudes and increase student creativity through their products (Darmi \& Setiawan, 2016). Learning Creative Products and Entrepreneurship students will find it easier to prepare themselves for the world of work because they have the right skills (Lestari \& Siswanto, 2015). By having skills, students will have the readiness to work in the industry and the world of work.

Readiness is a condition in which a person will not experience a significant problem or problem when doing a job. According to Eliyani \& Yanto (2016), vocational readiness includes students' abilities in logical and objective considerations, being critical, upholding responsibility for the work or task being done, and adapting to the environment.

Based on the explanation above, it is necessary to study how learning Creative Products and Entrepreneurship increases SMK Tata
Catering's work readiness.

\section{THEORETICAL REVIEW}

Vocational High School is a secondary level education that prepares students to work in specific fields. This is following the goals of vocational education, namely to produce a skilled workforce and to be able to develop their potential in adopting and adapting to developments in science, technology, and arts (Permendikbud No.34 of 2018). Based on these objectives, students who graduate from Vocational High Schools are expected to be skilled, independent, productive, and can immediately work professionally following their fields (Dyah et al., 2020).

However, the field's reality shows that there are still many Vocational High School graduates who have not been absorbed into the world of work, which indicates that vocational education goals are still not fully achieved . Based on data from the Central Statistics Agency in August 2019, as many as 7.05 million people were unemployed, and of this number, $10.42 \%$ came from Vocational High School graduates (Indonesian Central Statistics Agency, 2019). One of the causes of the high unemployment rate for vocational high school graduates comes from the number of jobs not proportional to vocational high school graduates. To overcome this, one way that can be done is to create new jobs.

Creative Products and Entrepreneurship subjects are taught to provide students with more knowledge and skills regarding entrepreneurship and are expected to foster students' interest in entrepreneurship. Students who later discontinue higher education are expected to have more interest in entrepreneurship, not only hunting for jobs or even increasing unemployment (Supena, Asep; Imas, Mastoah; Habudin; Gunawan, 2020). Creative Product and Entrepreneurship subjects have a role and contribution to foster students' interest in entrepreneurship (Khotimah, Kantun \& Widodo, 2020).

Work readiness for Vocational High School students is essential. This is because, in a short time, some or all students will face a higher level 
of life, namely work. In carrying out work activities, it is not easy. All types of work need to be prepared in advance. In connection with the very diverse types of work, the ways to prepare yourself for work also vary. Work preparation that needs to be done is mainly related to the work abilities required by a work type (Siwiyanti, 2017).

Work readiness is an advanced condition/process experienced by students where students' self-confidence grows after they feel ready to have the knowledge, attitudes, and skills needed by the world of work. Work readiness is influenced by (1) maturity level; (2) the necessary experiences; and (3) compatible mental and emotional states (Wiharja MS, 2019).

The world of work requires prospective workers ready to work and have competence according to industry needs. Educational institutions that aim to prepare job-ready workers are vocational high schools (SMK). Based on the National Education System Law No. 20 of 2003, Article 15 states that vocational education is secondary education that prepares students to work in specific fields. SMK to realize the government's goal of creating work-ready graduates is through any quality learning system. Learning in SMK applies the concept of dual system education. Dual system education is a form of providing education and vocational skills training that combines systematically and synchronously between education programs in schools and mastery of skills acquired through direct practice in the world of work (Eliyani, 2018).

\section{METHOD}

The approach used in this study is qualitative. This research was conducted in three stages, namely: (1) the first stage of research was carried out on learning entrepreneurial, creative products by conducting observation, interview, and documentation techniques related to planning, implementation, and evaluation, (2) The second stage of the research was carried out on the results of entrepreneurial, creative products that have been made by students using interview and documentation techniques, and (3) the third stage of the research was carried out on work readiness of Culinary Vocational High School students through interview techniques.

After conducting three research stages on learning entrepreneurial, creative products, the results of entrepreneurial, innovative products, and work readiness of Catering to Vocational High School students. Then the researchers analyzed the data that had been collected from observations, interviews, and documentation. The researcher then feels the information is interpreted as not answering the research focus questions, so it is necessary to hold a Focus Group Discussion to answer the questions more objectively and indepth. The data were analyzed and interpreted from the Focus Group Discussion results, and then conclusions were drawn from the research results.

This research was conducted at S.1 Vocational High School Surabaya, S.2 Vocational High School Surabaya, S.3 Vocational High School Surabaya, and S.4 Vocational High School Surabaya. Besides, this research was conducted at the PGRI Adi Buana University. The selection at S.1 Vocational High School in Surabaya, S.2 Vocational High School in Surabaya, S.3 Vocational High School in Surabaya, and S.4 Vocational High School in Surabaya is because this school is a tourism school that has a major in Catering. Besides, PGRI Adi Buana University's choice was because this University was the right location for conducting Focus Group Discussions that were neutral and easy to reach.

In this study, data were obtained from various sources using collection techniques such as observation, interviews, documentation, and Focus Group Discussion. Meanwhile, data analysis in qualitative research is carried out when data collection occurs and after completing data collection within a certain period. Research activities in qualitative data analysis are carried out interactively and continue until the data becomes saturated (Miles \& Huberman, 2012).

Furthermore, to obtain valid data, data checking techniques can be used, including (1) persistent observation, (2) triangulation (triangulation) of data sources and methods, (3) 
member checking (4), peer discussions (reviewing), and checking on the adequacy of references (referential adequacy checks) (Lincoln \& Guba, 1985).

\section{ANALYSIS RESULTS}

\section{A. Implementation of Creative Product and} Entrepreneurship Learning

Through interviews conducted by researchers with the Deputy Principal of Curriculum Affairs, Chair of the Culinary Expertise Program, and Creative Products and Entrepreneurship Teachers, the following research findings were obtained from October 18 - October 28, 2020.

At the planning stage of learning Creative Products and Entrepreneurship, the material presented follows the spectrum of expertise based on the Directorate of Vocational High School Development in 2018. Then at the implementation stage of learning entrepreneurial, creative products, it can be described as follows: (1) the source of the material used is only a book/module and the internet, (2) there is a need for material development, (3) class XI students are less active in learning entrepreneurial, creative products, (4) there is a need for product development of learning outcomes for Creative Products and Entrepreneurship, (5) students are still less able to think critically, ( 6) offline and online product marketing, (7) lack of capital in production, and (8) delivery of material to students.

Meanwhile, based on interviews conducted with students, the following research can be found Learning Creative Products and Entrepreneurship according to students having received material from teachers sourced from books and the internet, students still experience problems in selling products because teachers do not provide examples of food/beverage products that are of interest to the community.

Furthermore, based on the results of the implementation of the Focus Group Discussion, the following data were obtained:

Table 1 Implementation of Creative Product and Entrepreneurship Learning

\begin{tabular}{|c|c|c|}
\hline No & Research Sub Focus / Research Findings & Informant \\
\hline 1. & Suitability of Material with Basic Competencies & \\
\hline 1.1 & The material taught is following the 2018 Curriculum Spectrum. & S.3-WK.3 \\
\hline 1.2 & Following Basic Competence 3.1 to Basic Competence 3.14 . & S.2-KP.2 \\
\hline 1.3 & $\begin{array}{l}\text { The spectrum in Vocational High Schools, primarily Catering, is } \\
\text { still overlapping, but how smart are the Deputy Principals for } \\
\text { Curriculum, the head of the expertise program, and the productive } \\
\text { teachers respond to this so that the learning process continues } \\
\text { following the Basic Competencies. There must be standards } \\
\text { regarding the curriculum, but every teacher must make lesson plans } \\
\text { before the learning process begins, and in creating lesson plans, } \\
\text { there is no absolute truth. }\end{array}$ & D.2-N.2 \\
\hline 2. & Learning Resources Creative Products and Entrepreneurship & \\
\hline 2.1 & $\begin{array}{l}\text { Theoretically, we use books and the internet to be out of the } \\
\text { curriculum guide, but in general, practical learning refers to industry } \\
\text { and Micro, Small, and Medium Enterprises. }\end{array}$ & S.1-GR.1 \\
\hline 2.2 & $\begin{array}{l}\text { In addition to these two sources, it can be added by learning directly } \\
\text { from entrepreneurs/resource persons (Micro, Small and Medium } \\
\text { Enterprises). } \\
\text { Learning resources used in learning are sourced from books and the } \\
\text { internet as well as by conducting study tours to industry to foster }\end{array}$ & S.1-WK.3 \\
\hline
\end{tabular}




\begin{tabular}{|c|c|c|}
\hline & $\begin{array}{l}\text { student development in creativity (Forum Group Discussion, } \\
\text { Creative Products, and Entrepreneurship. S3-WK. 3) }\end{array}$ & \\
\hline & $\begin{array}{l}\text { Through industrial visits, life ins which are carried out a week } \\
\text { before the apprenticeship and apprenticeship. }\end{array}$ & S.1-WK.1 \\
\hline 3. & $\begin{array}{c}\text { Development of Creative Product and Entrepreneurship } \\
\text { Material }\end{array}$ & \\
\hline 3.1 & $\begin{array}{l}\text { The learning material provided follows the existing spectrum, but } \\
\text { there are shortcomings from the Industry and the World of Work. }\end{array}$ & S.4-WK.4 \\
\hline 3.2 & $\begin{array}{l}\text { It is appropriate, but there are still developments that are different } \\
\text { from the industrial world. }\end{array}$ & S.3-GR.3) \\
\hline 3.3 & $\begin{array}{l}\text { But most importantly, students can have a work culture character } \\
\text { after graduating. }\end{array}$ & I.1-H.1 \\
\hline 3.4 & $\begin{array}{l}\text { The most important thing for Vocational High School graduates is } \\
\text { the work culture's character because that's what I assess first to hire } \\
\text { recruits in my food and beverage food. }\end{array}$ & I.1-B.1 \\
\hline 4 & $\begin{array}{l}\text { Active and Critical Thinking in Creative Product Learning and } \\
\text { Entrepreneurship }\end{array}$ & \\
\hline 4.1 & $\begin{array}{l}\text { Because in class XI, children are still given material until they are } \\
\text { mature because children will enter the industry, and only in class XII } \\
\text { children have started to be creative because children have industrial } \\
\text { experience. }\end{array}$ & S.4-GR.4 \\
\hline 4.2 & $\begin{array}{l}\text { Students are very active and more critical in terms of } \\
\text { entrepreneurship. For students who are not yet operational, we make } \\
\text { learning through peers more practical in helping students. Besides, } \\
\text { since class XI, students are invited to create their online shop for } \\
\text { each individual. }\end{array}$ & S.3-KP.3 \\
\hline 4.3 & $\begin{array}{l}\text { Each individual is required to open their online shop. When class } \\
\text { XII is expected to be active in sharing with the juniors, the juniors } \\
\text { become open-minded to make students interested in learning and can } \\
\text { be responsible for developing an online store that I made me. }\end{array}$ & S.3-SW.3 \\
\hline 5 & Problems in Learning Creative Products and Entrepreneurship & \\
\hline 5.1 & $\begin{array}{c}\text { Marketing that has been carried out by Satya Widya Vocational } \\
\text { High School students is to use offline and online. Students usually } \\
\text { introduce their products through social media and word of mouth. } \\
\text { Teachers will free their students to make innovations in product } \\
\text { marketing. }\end{array}$ & S.4-WK.4) \\
\hline 5.2 & $\begin{array}{l}\text { Being a teacher is a role model for students. In terms of online } \\
\text { marketing, I hope that teachers have also had or have their online } \\
\text { store. So that students can learn appropriately from experienced } \\
\text { teachers. }\end{array}$ & D.2-N.2 \\
\hline 5.3 & $\begin{array}{l}\text { For capital, S.3 Surabaya Vocational High School collaborates with } \\
\text { students to provide financial assistance/loans as initial capital in } \\
\text { production. Later, the money can be returned in installments not to } \\
\text { hinder the production process carried out by students. }\end{array}$ & S.4-WK.4 \\
\hline
\end{tabular}




\begin{tabular}{|c|c|c|}
\hline 5.4 & $\begin{array}{c}\text { In the division of time, in Vocational High Schools, Creative } \\
\text { Product and Entrepreneurship learning are divided into 2, namely: } 2 \\
\text { hours of theory and } 6 \text { hours of selling at school. }\end{array}$ & S.2-GR.2 \\
\hline 5.5 & $\begin{array}{c}\text { Product work can be done outside of learning hours, or students } \\
\text { usually make products at their own homes. }\end{array}$ & S.4-GR.4 \\
\hline 6. & Delivering Material to Students & \\
\hline 6.1 & $\begin{array}{l}\text { There is a need for learning to be carried out between peers. } \\
\text { Teachers in evaluation can use benchmark assessments. }\end{array}$ & S.1-WK.1 \\
\hline 6.2 & $\begin{array}{l}\text { They must understand and be assisted by teachers to be able to } \\
\text { create products. }\end{array}$ & S.2-KP.2 \\
\hline 6.3 & $\begin{array}{l}\text { Assessment of mastery of abilities obtained by students should not } \\
\text { be based on norms but through benchmark references. So that the } \\
\text { learning outcomes obtained by students are objective, or students } \\
\text { have mastered the material presented. }\end{array}$ & D.2-N.2 \\
\hline
\end{tabular}

The research findings above, especially for the research focus "Exploration of Creative Product and Entrepreneurship Learning Implementation," can be concluded.

1. Material in Creative Product Learning and Entrepreneurship in Vocational High Schools follows Basic Competence 3.1 to Basic Competency 3.14, provided by the Directorate of Vocational High School Development in 2018.

2. Learning resources used in Creative Product Learning and Entrepreneurship in Vocational High Schools include books and the internet, learning directly from entrepreneurs/resource persons (Micro, Small and Medium Enterprises), study tours to industry, and industrial visits, a life in which is conducted a week before the internship and apprenticeship.

3. Development of material in Learning Creative Products and Entrepreneurship in Vocational High Schools, among others: according to the spectrum but there are deficiencies from the Industry and the World of Work, but the important thing is that Vocational High School graduates have a work culture character and hire new prospective workers in culinary.

4. Cultivate active attitudes and critical thinking in Creative Product Learning and Entrepreneurship in Vocational High Schools: students have started to be involved. They think critically because they already have experience in the industrial world. Class XII is active in sharing with younger class members in entrepreneurship and making students interested in learning and can be responsible for developing online stores that are made individually.

5. Problems in Learning Creative Products and Entrepreneurship are students who still experience selling products because teachers do not provide examples of food/beverage products of interest to the community. Besides that, another problem in learning Creative Products and Entrepreneurship is a lack of capital.

6. Delivery of material to students in learning Creative Products and Entrepreneurship in Vocational High Schools is carried out with peers, and teachers help students create products. In assessing the mastery of students' abilities, it should not be based on reference to norms, but through benchmarks, so that students' learning outcomes are objective or students have mastered the material presented.

\section{B. Work Readiness of Catering Vocational High School Students}

Based on researchers' interviews to determine the conditions of work readiness of students of the Catering Vocational High School in Vocational High Schools, the recording of the interview results can be seen in the following description below.

According to the Deputy Principal for Curriculum Affairs, Chair of the Culinary 
Expertise Program and Creative Products and Entrepreneurship Teacher regarding the work readiness of Catering Vocational High School students, it can be concluded as follows: (1) Students are still unable to actively think critically in solving problems and (2) students even need guidance and direction in doing business planning.

Meanwhile, the interviews' results regarding work readiness conducted by researchers with students, the findings of which can be stated below.

Students have received guidance and direction given by the teacher regarding processing techniques for processed and frozen food products. Besides, schools provide capital loans for the practice of learning Creative Products and Entrepreneurship, the return of which is paid in installments from the profits from the sales earned. So that students have experience working in learning Creative Products and Entrepreneurship.

Furthermore, in equating the perceptions of understanding Culinary Vocational High School students' work readiness in learning Creative Products and Entrepreneurship, researchers need to hold a Focus Group Discussion whose results can be seen in Table 2 below.

Table 2 Work Readiness of Catering Vocational High School Students

\begin{tabular}{|c|c|c|}
\hline No & Research Sub Focus / Research Findings & Informant \\
\hline 1. & Active and Critical Thinking in Problem Solving & \\
\hline 1.1 & $\begin{array}{l}\text { The basis for this statement was from my personal experience when } \\
\text { I was at school. The teacher must provide direction and provide the } \\
\text { answer key to any problems that students have. Teachers can be } \\
\text { motivators and must have a teacher's soul. }\end{array}$ & I.2-B.1 \\
\hline 1.2 & $\begin{array}{c}\text { Teachers can guide and motivate students and need support from } \\
\text { parents. Besides, the students themselves' personality factor who } \\
\text { must be brave to continuously learn from mistakes is also } \\
\text { significant. }\end{array}$ & S.3-KW.3 \\
\hline 2. & Improving Student Ability in Business Planning & \\
\hline 2.1 & $\begin{array}{l}\text { Students have been able to open their businesses through online } \\
\text { stores made by each individual and focus on marketing on other } \\
\text { social media platforms. }\end{array}$ & S.3- \\
\hline 2.2 & $\begin{array}{c}\text { Most of them have been able to open their businesses even though } \\
\text { they are selling online using IT media. Besides, students with the } \\
\text { help of teachers through learning Creative Products and } \\
\text { Entrepreneurship can learn about maturing students' abilities } \\
\text { regarding planning to open a business starting from production, } \\
\text { marketing (sales), evaluation. }\end{array}$ & K.4 \\
\hline 2.3 & $\begin{array}{l}\text { Currently, students feel that they can be released, but guidance is } \\
\text { still carried out even though they must be ready to guide them until } \\
\text { their efforts develop optimally and optimally. }\end{array}$ & KP.4 \\
\hline 3. & Creative Product and Entreprenes & \\
\hline 3.1 & $\begin{array}{l}\text { Students have been able to plan practice, especially active students, } \\
\text { systematically. }\end{array}$ & S.3-WK.3 \\
\hline 3.2 & $\begin{array}{l}\text { By compiling a structured design starting from business planning, } \\
\text { production, and product marketing methods. }\end{array}$ & S.4-GR.4 \\
\hline 3.3 & Students are guided in drafting a business plan. & S.1-WK.1 \\
\hline
\end{tabular}




\begin{tabular}{|c|c|c|}
\hline 4. & $\begin{array}{r}\text { Entrepreneurial Attitudes in Working Independently or Opening } \\
\text { Your Own Business }\end{array}$ & \\
\hline 4.1 & Participants can open their jobs even on a small scale. & S.4-WK.4 \\
\hline 4.2 & $\begin{array}{r}\text { Sufficiently capable because it is evident from the results of practice } \\
\text { at school. }\end{array}$ & S.3-GR.3 \\
\hline 4.3 & $\begin{array}{r}\text { Intensive guidance is needed so that the resulting student efforts can } \\
\text { develop. }\end{array}$ & S.2-SW.2 \\
\hline 4.4 & $\begin{array}{c}\text { There must be an alignment between the curriculum and industry so } \\
\text { that an MoU or an agreement between the industry and schools may } \\
\text { be needed to apply this harmony in the future. }\end{array}$ & D.2-N.2 \\
\hline
\end{tabular}

The research findings above, especially for the focus of the research "Work Readiness of Catering Vocational High School Students," can be concluded as follows.

a. Students have started to be active and think critically because they already have experience in the industrial world, share with the younger class in entrepreneurship and make students interested in learning, and can be responsible for developing online shops that are made themselves.

b. Students can make planning, production, marketing (sales), and evaluation and open their own business through an online shop by utilizing IT. The teacher in this activity still guides students until the efforts are made to develop optimally.

c. Students have systematically compiled a structured Creative Product and Entrepreneurship business plan starting from business planning, production, and integrated marketing methods while remaining under Creative Products and Entrepreneurship teachers' guidance.

d. Students have been able to open their jobs even though on a small scale and still need intensive guidance so that students' businesses develop and establish cooperation (MoU) with relevant industry parties.

e. Students have received guidance and direction given by the teacher regarding processing techniques for processed and frozen food products. Besides, schools provide capital loans for the practice of learning Creative Products and Entrepreneurship, the return of which is paid in installments from the profits from the sales earned. So that students have experience working in learning Creative Products and Entrepreneurship.

\section{Culinary Product Innovations Developed by Students as Work Readiness}

Based on the interviews conducted by researchers to find out the innovations of products in the culinary field developed by students as a provision for student work readiness, it can be stated below.

Regarding innovations in culinary products developed by students as a provision for student work readiness, it can be concluded that students have received guidance and direction from the teacher regarding materials, processing techniques, decoration, and packaging and how to sell both directly and online. Besides, students can make processed food products with innovations of interest to the public regarding raw materials, cooking techniques, and presentation.

Furthermore, students' product innovations as a provision for student work-readiness using documentation data collection techniques in the form of photos of creative culinary products are described in Figures 1 to 5 below. 


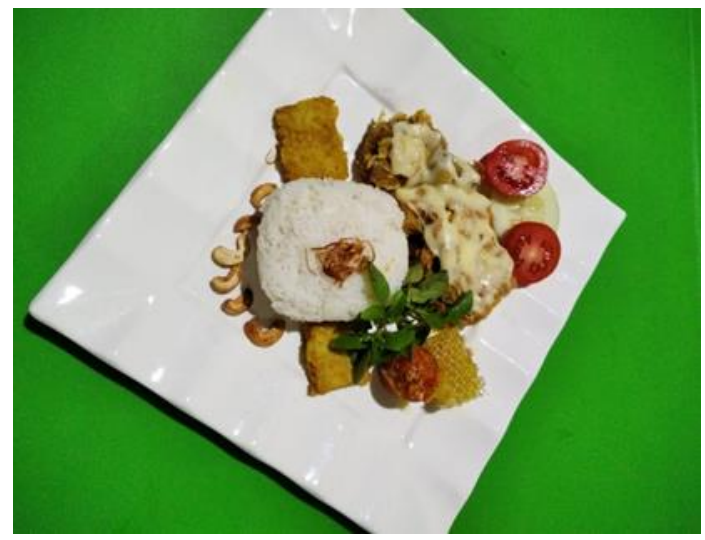

Figure 1 Bright Moon

\section{Information:}

This Angel's Moonlight has a difference from the normal moonlight, which includes its shape, appearance, taste, texture, and presentation.

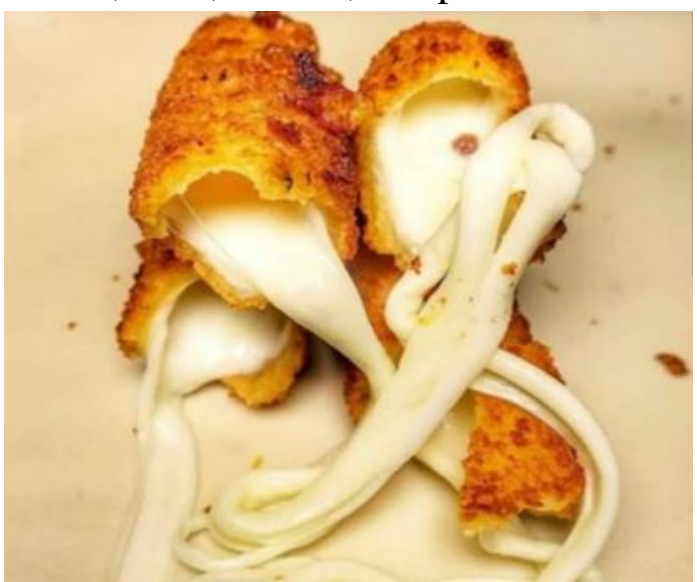

Figure 2 Rissoles

\section{Information:}

The special mayo rissoles have an advantage compared to the usual mayo rissoles because they have a characteristic taste of continental dishes with mozzarella, oregano, leaf flavors, and tobacco sauce ordered directly / cooked or frozen.

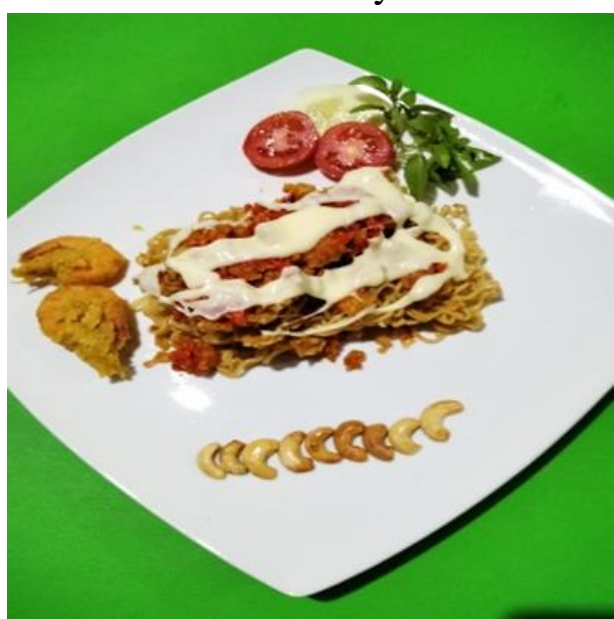

Figure 3 Special Geprek Chicken Noodles
Information:

Chicken Noodle Geprek, cucumbers, and tomatoes.

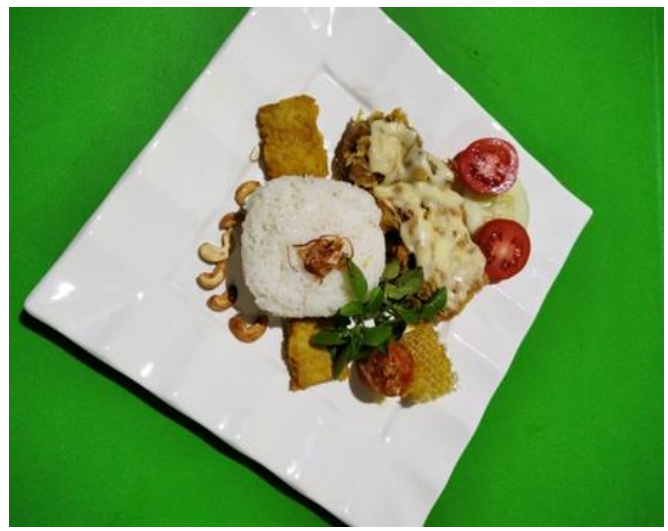

Figure 4.4 Geprek Chicken Rice with Honey Sauce

\section{Information:}

Geprek Chicken Rice with Honey Sauce has the advantages of ordinary Geprek chicken rice, where this special Geprek chicken rice has the taste of Indonesian and continental cuisine. This geprek chicken rice is complemented with mozzarella sauce, real honey plus fried tempeh, fried cashews, and chili sauce.

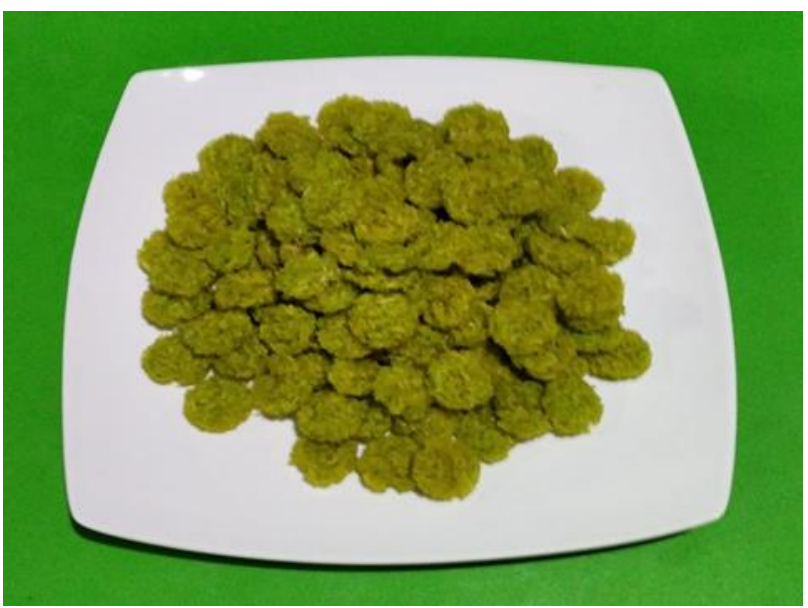

Figure 4.5 Rengginang crackers

\section{Information:}

This Rengginang Kelor cracker has the advantage of ordinary rengginang because it is a substitute for Moringa leaves, where the community now believes that Moringa leaves have many benefits.

Figures 1 to 5 above show that Vocational High School students' food products have innovations in organoleptic, including ingredients, texture, appearance, taste, and creativity. They already have the basics of knowledge in creating a 
design. Products or can create a new product but does not leave the characteristics of the product itself.
Furthermore, from the researcher's implementation of the Focus Group Discussion, research findings can be obtained, as shown in Table 3 below.

Table 3: Culinary Product Innovations Developed by Students as Work Readiness

\begin{tabular}{|c|c|c|}
\hline No & Research Sub Focus / Research Findings & Informant \\
\hline 1. & Hasil Produk Pembelajaran Produk Kreatif dan Kewirausahaan & \\
\hline 1.1 & $\begin{array}{l}\text { Students are given an overview of the market's products to } \\
\text { choose from and make more innovative products, for example, } \\
\text { "Frozen." }\end{array}$ & S.1-WK.1 \\
\hline 1.2 & $\begin{array}{l}\text { Students can provide product innovations by looking at the } \\
\text { internet and others. }\end{array}$ & S.3-WK.3 \\
\hline 1.3 & $\begin{array}{l}\text { As time goes by, they practice selling they can make product } \\
\text { innovations. }\end{array}$ & S.4-WK.3 \\
\hline 2. & Increased Sales through Offline and Online Marketing & \\
\hline 2.1 & $\begin{array}{l}\text { At school, we sell in two ways: online and offline, and both have } \\
\text { been running smoothly. }\end{array}$ & S.1-KP.1 \\
\hline 2.2 & $\begin{array}{l}\text { Online, using the grab / gofood application and making it more } \\
\text { efficient, students use the PO (Pre Order) system. }\end{array}$ & S.1-GR.1 \\
\hline 2.3 & $\begin{array}{l}\text { Through promotions, brochures, social media, and the Open Pre } \\
\text { Order system. }\end{array}$ & S.3-WK.3 \\
\hline 2.4 & $\begin{array}{l}\text { Marketing through online so that the product is more widely } \\
\text { known and offline marketing is used, so that product results are } \\
\text { right on target (door-to-door sales). }\end{array}$ & S.2-GR.2 \\
\hline 3. & $\begin{array}{l}\text { Increasing Student Innovation in Making Products that are } \\
\text { Easy to Accept in Society }\end{array}$ & \\
\hline 3.1 & $\begin{array}{l}\text { The product has been accepted by the community, proven by } \\
\text { testimonials from buyers. }\end{array}$ & S.3-WK.3 \\
\hline 3.2 & $\begin{array}{l}\text { Our student products have been accepted in the community, for } \\
\text { example, frozen food products that students made during the } \\
\text { pandemic. So the role of the teacher in providing directions in } \\
\text { providing innovation in more attractive packaging. }\end{array}$ & S.4-WK.4 \\
\hline 3.3 & $\begin{array}{l}\text { To increase the innovativeness of a product, it can be done by } \\
\text { increasing: (1) Product Packaging, (2) Product Appearance, ( } 3 \text { ) } \\
\text { Product Taste, (4) Product Prices so that the product is expected } \\
\text { to compete with other Micro, Small and Medium Enterprises } \\
\text { products. }\end{array}$ & S.1-GR.1 \\
\hline 3.4 & $\begin{array}{l}\text { Increasing food and beverage product innovation can be by } \\
\text { introducing old products with more unique and varied names. }\end{array}$ & S.4-GR.4 \\
\hline
\end{tabular}


Based on the research findings above, especially for the research focus of "Food Innovations Developed by Students as Work Readiness Provisions," it can be concluded as follows.

1. Food products processed by Vocational High School students have innovations in terms of organoleptic which include ingredients, texture, appearance, taste, and creativity because they already have the basics of knowledge in creating product innovation or can create a new product but do not leave their mark of the product itself.

2. Students are given an overview of the products on the market from the internet to make product innovations over time.

3. Students receive guidance and direction from the teacher regarding materials, techniques for processing, decorating, packaging, and selling both in-person and online. Marketing is also carried out through promotions, brochures, social media, and an open pre-order system.

4. Students can make processed food products with innovations of interest to the public regarding raw materials, cooking techniques, and presentation.

5. Culinary product innovations developed by students as a provision for student workreadiness using documentation data collection techniques in photographs of creative culinary products.

\section{DISCUSSION}

\section{A. Exploration of Creative Product and Entrepreneurship Learning Implementation}

One of the learning conditions that can support competency achievement is developing a student activity-based learning process with a background in world work activities. Learning that needs to be designed to build competence is an interaction that allows students to develop their knowledge, attitudes, and skills through various modes of learning experience transformation (Lastariwati, 2013).

Planning for learning entrepreneurial, creative products begins with preparing a Learning Implementation Plan made by the teacher to be the basis for students' teaching and learning activities. The Learning Implementation Plan's formulation is based on Basic Competencies following the Directorate of Vocational High School Development guidelines in 2018. From the results of researchers' observations on entrepreneurial, creative product teachers, they have compiled a Learning Implementation Plan following the Basic Competencies given by the Directorate of Vocational High School Development in 2018. This statement was also supported by the Focus Group Discussion results delivered by the Deputy Principal for Curriculum, which explained that the material presented to students was following the curriculum spectrum of Culinary Vocational High School students' expertise. 2018. But this statement was refuted by the Vocational High School supervisor, who explained that the implementation of the curriculum spectrum in Culinary Expertise Vocational High Schools still overlaps with each other. Other, but the misalignment of these materials can be minimized by mastering useful material concepts from every Creative Product and Entrepreneurship teacher. Because teachers in Vocational High Schools are a dominant part of learning, where qualified teachers will have a positive impact on learning (Indayati, 2017)

This study's findings indicate that the implementation of Creative Product and Entrepreneurship learning in Culinary Expertise Vocational High Schools in Vocational High Schools uses two primary learning sources: books and the internet. The two primary sources are learning resources by design because they are deliberately designed to be a learning resource (Jalinus \& Ambiyar, 2016). Besides, the findings of other learning resources at the Vocational High School on this research site include direct learning from entrepreneurs/resource persons for Micro, Small, and Medium Enterprises, study tours to industry, and industrial visits, life in which is done a week before the internship.

The third is evaluating the learning process of entrepreneurial, creative products needed to find out the shortcomings and overcome the problems faced in learning using critical thinking carried out 
by Culinary Vocational High School Students. Critical thinking encourages students to be able to analyze and evaluate all forms of problems in their thinking so that they can be resolved by considering risks and making decisions appropriately and accurately (Ariyanto et al., 2018)

Research (Maryanti et al., 2020) about the rapid industrial revolution 4.0, based on the findings of her study in 5 (five) Vocational High Schools, shows that Vocational High Schools align education with the demands of the Industrial Revolution 4.0 era, namely improving the quality of facilities and infrastructure based on industrial needs (link and match). They improve competencies following the Industrial Revolution era 4.0, then made competently and graduates ready to align with the Making Indonesia 4.0 program launched by the Ministry of Industry.

Research on learning Entrepreneurship Creative Products was reviewed by Khotimah, Kantun, and Widodo (2020). The researchers' results showed that the learning outcomes variable in Creative Products and Entrepreneurship subjects significantly affected entrepreneurship's student interest.

Based on the discussion above, it can be argued that learning Entrepreneurship Creative Products in Vocational High Schools is following Core Competencies and Basic Competencies. However, in its implementation, it still needs to be further developed. Research shows that success in learning entrepreneurial, creative products in vocational high schools impacts students' entrepreneurial interests.

\section{B. Work Readiness of Catering Vocational High School Students}

Data collection results on student readiness indicate that the students' grades for work readiness are capable and ready to work in the industry and the world of work. The study's findings suggest that by learning Entrepreneurship Creative Products, Tata Catering Vocational High School students' work readiness competencies have been able to open their businesses. Although in practice, they are still in mentoring, fostering, and supervising
Entrepreneurship Creative Product teachers in Vocational High Schools.

Tata Catering Vocational High School, students' readiness in opening their own business, including students, can calculate how much profit from the products they make. Meanwhile, the gain is obtained from calculating the cost of goods and the selling price. The production cost is needed to calculate the selling price, estimate profits, and set its strategy. Therefore, Vocational High School students must be equipped with how to calculate the cost of production.

Apart from calculating the cost of goods manufactured, the company must also calculate the Break-Even Point analysis. This is because BreakEven Point analysis is very important for corporate financial reporting. The cost of production and Break-Even Point analysis will later be used to compare with income and are presented in the company's match and loss report. To understand more clearly about the cost of goods manufactured and Break-Even Point analysis.

Every graduate of educational institutions, both formal and non-formal, will engage in society or the world of work and face the real world with all its demands. Demands continue to increase over time with the times. Therefore, education in planning, management, and implementation must adjust to field needs (Krisnamurti, 2017).

Vocational High School is a secondary education that prepares students to be ready to work following their field. Currently, advances in technology and knowledge and globalization have made the goods and services industry continue to develop (Wahyuningsih \& Yulianto, 2020). As a type of education, Vocational High Schools are believed to be schools capable of creating innovative, creative, and productive educational products. Vocational High Schools, as educational institutions that prepare workers, focus on training workers to fill industrial jobs and prepare them to be independent, namely becoming entrepreneurs who can create jobs for themselves and others. This is in line with the results of research conducted by (Prikshat et al., 2019) that there are four essential indicators in job readiness, namely: (1) Intellectual 
Resources, (2) Personality Resources, (3) Meta Skills Resources, and ( 4) Job Specification Resources.

Based on the above discussion, it can be argued that the students of the Catering Vocational High School at the Vocational High School in the research location indicated that they had gone through a long enough process to be prepared to have work readiness. Many factors can be identified that contribute to vocational high school students' job readiness, including provisioning at school, experience during industrial internships, and career guidance at school.

\section{A. Culinary Product Innovations Developed by Students as Work Readiness}

Vocational High Schools are believed to create innovative, creative, and productive educational products as a type of education. Vocational High Schools as an educational institution that prepares the workforce, not only focuses on training workers to fill industrial jobs but is also ready to be independent, namely becoming entrepreneurs who can create jobs for themselves and others (Murniati et al., 2018).

Creativity and innovation are essential elements in entrepreneurship. Creativity, design, and entrepreneurship are three things that synergize into one that cannot be separated in business activity. Creativity is the emergence of new ideas. Innovation is an implementation of these ideas to become a product that can meet society's needs and desires. With creativity and innovation, a business or business can have a competitive advantage and maintain its survival longer. With creativity and innovation, a trade or business can be superior and different from its competitors' products (Zimmerer \& Scarborough, 2008).

The practice of innovation and creativity can be done through collaboration with higher education institutions. As stated by Hudiah, Pratama, and Qur'ani (2020), The results of the study show that: (1) partners acquire the knowledge needed in modifying traditional cakes, (2) partners acquire knowledge in utilizing local fruits and vegetables, such as pumpkin, sweet potato, and carrots, (3) partners have acquired knowledge and skills in using simple technology in making Cucur Bayao, (4) partners have skills in creating and utilizing local fruits and vegetables, such as pumpkin, sweet potato, and carrot.

Based on the above discussion, it can be concluded that innovation and creativity in the processing and presentation of food products cannot be ignored because creativity in food products will have a selling value and an appeal to potential consumers. Innovation and creativity keep pace with the increasingly rapid development of information technology, however, while still emphasizing the originality of Indonesia's cultural identity.

\section{Recommendations from the Research Findings}

Based on the research findings regarding the development of Creative Products and Entrepreneurship learning materials that have been described above. The researcher recommends the learning design in Figure 4 below. 


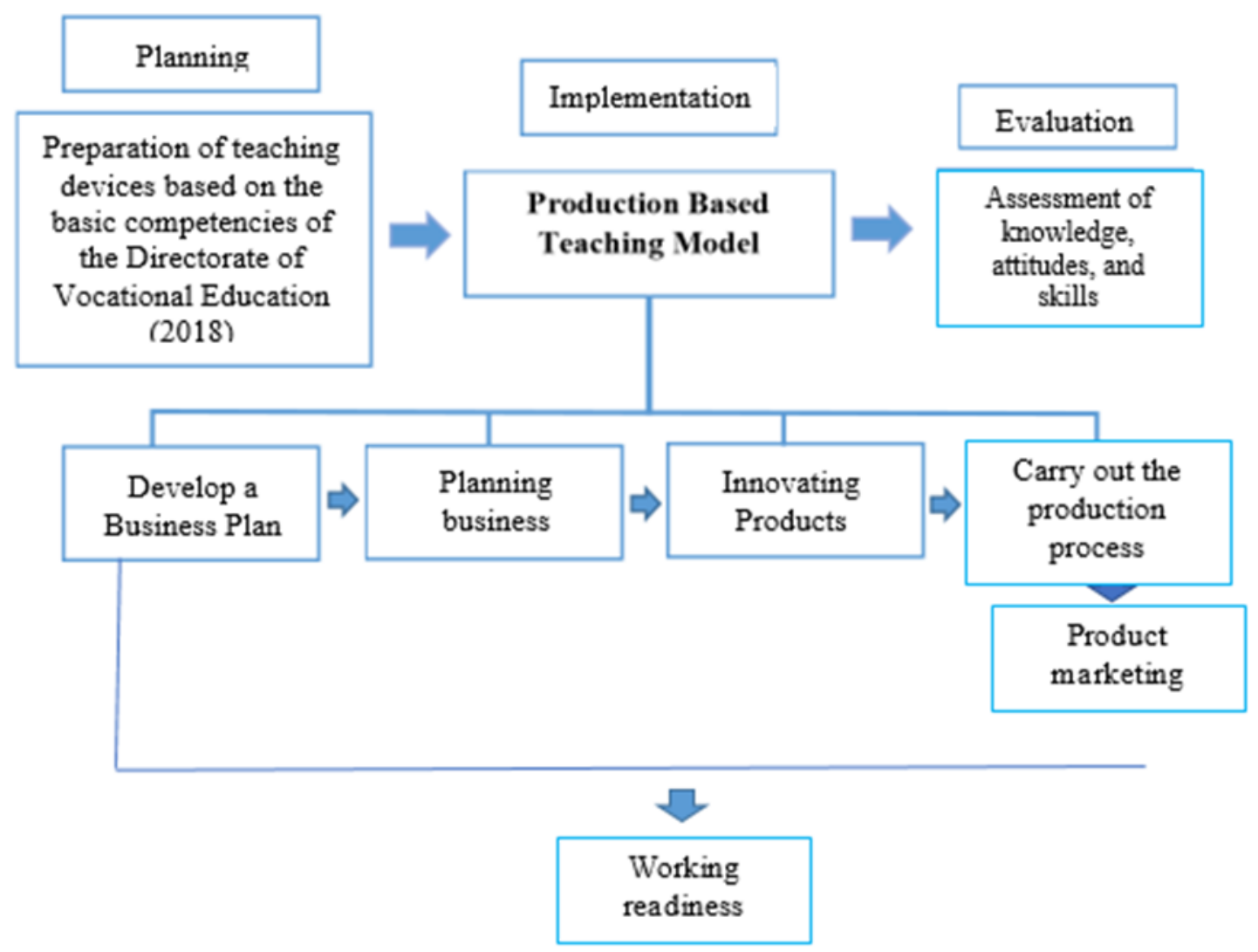

Figure 4 Recommendations on Creative Product and Entrepreneurship Learning Designs

The learning model in Figure 4 above was adapted from the Production Based Training learning model, according to Jenkins \& Unwin (2012). This model is an education and training process integrated into the production process. Students are given learning experiences in contextual situations following the industrial workflow starting from planning based on orders, implementing and evaluating products/product quality control, and post-production service steps. The purpose of using the Production Based Training learning model is to prepare students to have work competencies related to technical competencies and the ability to collaborate (collaborate) according to the work organization's demands. The syntax for the stages of the Production Based Training learning model includes: (1) planning the product, (2) carrying out the production process, (3) evaluating the product (performing quality control), and (4) developing a marketing plan.

Based on the findings of research on Creative Product Learning and Entrepreneurship for Vocational High School Students with Culinary Skills in Vocational High Schools that have been described earlier, by paying attention to the stages of the learning model mentioned above, it can be described in detail in the following description

1. Plan the product.

Making product plans can be in the form of production objects that can be done from the start to drawing details / making pamphlets. The study's findings show that in this planning, there are 4 (four) principles that are applied in doing product planning, the 4Ps (Price, Place, Plan, and Promotion). Students have more up to date ideas about products that are booming/trending in today's society.

2. Carry out the production process.

Students are invited to carry out the production stages in this syntax based on product planning/service/performance planning, workflow/work coordination, and monitoring the production process. In detail, the research findings show that in the implementation of the production 
process, it is necessary to pay attention to the following matters: (a) creating products according to community interests, (b) making business administration documents, (c) planning regarding business resource requirements, (d) creating systems business services, (e) Break-Even Points in business creation, (f) simple financial reports, and (g) planning the results of business evaluation.

3. Evaluating the product (doing quality control).

In this step, students are invited to check product results by comparing them with technical planning demands. A product is anything that can be offered to the market to satisfy a need or desire. Through products, producers can pamper consumers. Because of the product, it will be known how much satisfaction and demand for the product itself in the consumer's life. In producing products, producers should be following the needs and desires of consumers. In efforts to satisfy consumer needs, producers need to innovate. Innovation, namely creative and innovative people who always want to try new and original ideas to achieve effectiveness and efficiency in carrying out their work.

To increase the innovativeness of the resulting product, steps are taken to improve the innovativeness of a product by increasing: (1) product packaging, (2) product appearance, (3) product taste, and (4) product price so that the product is expected to compete with other UMKM products.

According to (Thuy \& Hong, 2019), there are three indicators of product innovation, namely: (a) Product Quality, (b) Product Variants, and (c) Product Style and Design. Besides that, students of the Catering Expertise Vocational High School made innovations on the products they made. Product innovation is carried out by applying variations and product variants using production processing techniques with the Frozen approach.

4. Develop a Marketing Plan.

Students are invited to prepare marketing plans both in networks and outside networks in pamphlets and present them. The findings of the research, marketing methods that have been carried out by Vocational High School Students with
Culinary Expertise, include: (a) students' products in the form of food and beverages are introduced/traded offline and online, and (b) apply the core of promotion first sell, then open the Pre Order system.

The learning model for Creative Products and Entrepreneurship (Figure 4) above in this study is recommended as a learning model that can shape Vocational High School Students' work readiness with Culinary Skills.

\section{CLOSING}

\section{Conclusion}

Based on the focus of research, exposure and data analysis and discussion, it can be concluded as follows: (1) Learning Creative Products and Entrepreneurship in Vocational High Schools is in accordance with Basic Competencies using book learning resources, the internet, direct learning in the business world and the industrial world, emphasizing on planting an active attitude and critical thinking, and by applying the Production Based Teaching Model; (2) the work readiness of the students of SMK Tata Boga is shown by the following performance: students are able to make planning, production, integrated marketing and evaluation, open their own business through online shops, and are able to open their own jobs even though on a small scale, and (3) innovations in food products that can be developed by students as a provision for work readiness are represented by: (a) students are able to make processed food products with innovations that are of interest to the public both from the organolebtic aspects which include ingredients, texture, appearance, taste and creativity, processing techniques, decorating, packaging and presentation, and (b) selling products both directly and online as well as marketing with promotions, brochures, social media and an open pre order system.

\section{Suggestion}

Based on these conclusions, it can be suggested to teachers of Creative Products and Entrepreneurship to streamline Creative Products and Entrepreneurship learning, so teachers need to 
apply a learning model with the Production Based Teaching Model design found in the research to be used to Kealian Catering Vocational School Students in SMK

\section{REFERENCES}

[1] Adrianto. (2016). Pencatatan Akuntansi Pada Usaha Mikro,Kecil,Dan Menengah(UMKM) Terhadap Implementasi Standar Akuntansi Entitas Tanpa Akuntabilitas Publik (SAK-ETAP). Majalah Ekonomi _ ISSN No. 1411-9501 _Vol. XX No. 2 Des 2016.

[2] Andriani, W., Setyosari, P., Kuswandi, D., Kamdi, W., Gunawan, W., Karyono, H., \& Student, G. (2020). Application of MURDER Collaborative Learning and Achievement Motivation on ProblemSolving Skills. International Journal of Innovation, Creativity, and Change. Www.Ijicc.Net, 14(2), 2020. Retrieved from www.ijicc.net

[3] Ariyanto, M., Kristin, F., \& Anugraheni, I. (2018). Penerapan Model Pembelajaran Problem Solving untuk Meningkatkan Kemampuan Berpikir Kritis dan Hasil Belajar Siswa. Jurnal Guru Kita.

[4] Badan Pusat Statistik Indonesia. (2019). Keadaan Ketenagakerjaan Indonesia Agustus 2019. In Badan Pusat Statistik.

[5] Ciana, N. P., \& Rahmi, E. (2020). Pengaruh Pelaksanaan Pembelajaran Kewirausahaan dan Efikasi Diri terhadap Kesiapan Berwirausaha Siswa Kelas XII di SMKN 1 Lubuk Basung. Jurnal Ecogen.

[6] Darmi, Y., \& Setiawan, A. (2016). Penerapan Metode Clustering K-Means Dalam Penjualan Produk. Y. Darmi, A. Setiawan.

[7] Dyah, A., Arum, A., \& Marlena, N. (2020). Pengaruh Pembelajaran Kewirausahaan dan Keikutsertaan dalam Prakerin Terhadap Minat Berwirausaha Siswa SMK. Jurnal Pendidikan Ekonomi, Manajemen Dan Keuangan.

[8] Eliyani, C., \& Yanto, H. (2016).
Determinan kesiapan kerja siswa SMK kelas XII kompetensi keahlian akuntansi di Kota Semarang. Journal of Economic Education, 5(1), 22-30

[9] Gunawan, W., Nyoman Sudana Degeng, I., \& Utaya, S. (2019). The Improvement of Conceptual and Procedural Understanding by Scaffolding with Responsiveness. In International Journal of Innovation, Creativity, and Change. www.ijicc.net (Vol. 7). Retrieved from www.ijicc.net

[10] Hudiah, A., Pratama, N.H. \& Qur'ani, B. (2019). Innovation Of Traditional Cakes Made Of Vegetables And Fruits By Craft Subject Teachers' Working Group. Journal of Society Engagement (PJSE), ISSN 2715453X, Vol. 1, No. 2, March 2020, pp. 1-6.

[11] Indayati, W.

(2017).

PengembanganPembelajaranPrakaryadanK ewirausahaan Model Project Based Learning di SMK Negeri Malang. In DISERTASI dan TESIS Program Pascasarjana UM.

[12] Jalinus, N., \& Ambiyar. (2016). Media dan Sumber Pembelajaran. Sifonoforos.

[13] Jenkins dan Unwin. (2011). Proses pembelajaran. Jakartya:Raja Grafindo Persada.

[14] Khotimah, P.C., Kantun, S. \& Widodo, J. (2020). Pengaruh Hasil Belajar Mata Pelajaran Produk Kreatif dan Kewirausahaan Terhadap Minat Berwirausaha Siswa di SMK Negeri 7 Jember (Studi Kasus pada Kelas XII Program Keahlian Multimedia Semester Gasal Tahun Ajaran 2019/2020). Jurnal Pendidikan Ekonomi: Jurnal Ilmiah Ilmu Pendidikan, Ilmu Ekonomi, dan Ilmu Sosial, Volume 14 Nomor 2 (2020).

[15] Krisnamurti, T. F. (2017). Mempengaruhi, Faktor-faktor Yang Kerja, Kesiapan Siswa SMK. Jurnal Pendidikan Dan Ekonomi.

[16] Lastariwati, B. (2013). Pentingnya kelas kewirausahaan pada SMK Pariwisata. Jurnal Pendidikan Vokasi.

[17] Lincoln, Y. S., \& Guba, E. G. (1985). 
Naturalistic injury. In Volume 75.

[18] Maryanti, N., Rohana, R., \& Kristiawan, M. (2020). The Principal's Strategy in Preparing Students Ready to Face the Industrial Revolution 4.0. International Journal of Educational Review.

[19] Maulana, S. M., Susilo, H., \& Riyadi. (2015). Implementasi E-Commerce Sebagai Media Penjualan Online. Jurnal Administrasi Bisnis.

[20] Miles, M. B., \& Huberman, M. A. (2012). Analisis Data Kualitatif: Buku Sumber Tentang Metode-Metode Baru. In Universitas Indonesia_UI Press.

[21] Murniati, M., Usman, N., Husen, M., \& Irani, U. (2018). Penerapan sistem standar mutu ISO 90012008 pada sekolah menengah kejuruan. Jurnal Akuntabilitas Manajemen Pendidikan.

[22] Prikshat, V., Kumar, S., \& Nankervis, A. (2019). Work-readiness integrated competence model: Conceptualisation and scale development. Education and Training. https://doi.org/10.1108/ET-052018-0114

[23] Rokhmadi, M. A. (2019). Penerapan Metode Reward untuk Meningkatkan Hasil Belajar Produk Kreatif dan Kewirausahaan dengan Materi Peluang Usaha. Journal of Education Action Research. https://doi.org/10.23887/jear.v3i4.22333

[24] Siwiyanti, L. (2017). Menanamkan Nilai Kewirausahaan Melalui Kegiatan Market Day Embedding the Entrepreneurship Values through Market Day Activity. Jurnal Pendidikan Anak Usia Dini.

[25] Supena, Asep; Imas, Mastoah; Habudin; Gunawan, W. (2020). Improving Teacher Competence In Inclusive. 17(8), 249-266.

[26] Thuy, T. T., \& Hong, P. T. T. (2019). Attitude to and Usage Intention of High School Students Toward Electric TwoWheeled Vehicles in Hanoi City. VNU Journal of Science: Economics and Business.

[27] Undang-Undang Nomor 20 Tahaun 2003 tentang Sistem Pendidikan Nasional.

[28] Wahyuningsih, I., \& Yulianto, A. (2020). Pengaruh Status Sosial Ekonomi Orang Tua dan Praktik Kerja IIndustrI Melalui Motivasi Kerja terhadap Kesiapan Kerja. Economic Educatio Analysis Journal.

[29] Wiharja MS, MS. (2020). Pengaruh Pengalaman Praktek Kerja Industry dan Internal Locus Of Control Terhadap Kesiapan Kerja Siswa SMK. Jurnal FamilyEdu. Vol V No.1 April 2019

[30] Zimmerer, T. W., \& Scarborough, N. M. (2008). Kewirausahaan dan Manajemen Usaha Kecil. In Salemba Empat 